\title{
Framework for Assessment of Climate Change Related Risks to Buildings
}

\author{
Devika Nayal \\ Department of Building Engineering and Management \\ School of Planning and Architecture, \\ New Delhi \\ Prof. Dr. Chaitali Basu \\ Department of Building Engineering and Management \\ School of Planning and Architecture \\ New Delhi
}

\author{
Varun Seth \\ Department of Building Engineering and Management \\ School of Planning and Architecture \\ New Delhi \\ Prof. Dr. Virendra Kumar Paul \\ Department of Building Engineering and Management \\ School of Planning and Architecture \\ New Delhi
}

\begin{abstract}
The paper addresses the increasing risk change in climate poses to building operation and durability. Investors have started to realize that climate change-based risks may affect long term profitability of their assets. The financial impact of these risks is ambiguous, but various studies have been conducted on how durability of built environment is impacted by change in climatic conditions. A framework has thus been formulated that assesses risks to a region or city through indicators for flooding, rise in temperature, poor air quality, rapid urbanization and water scarcity derived from literature. The relative importance of each risk has been derived through survey and the framework has been applied on cities of Chennai, Delhi and Mumbai.
\end{abstract}

\section{Keywords-Climate Change, Risk Assessment, Indicators}

\section{BACKGROUND}

The causal relationship between human activities and climate change has been well established and acknowledged globally. However, during the last few decades it has been observed that not only the human activities impact climate change, but the change in climate has resulted in severe effect on human activities; this change carries the potential to alter both the man made and natural systems in all the oceans and all the continents [1]. The reports by the European Commission and the Urban Land Institutes brings forth the impacts the change in climatic factors are likely to have on the built environment in terms of environmental, social and operational performance and financial implications, the ULI report on the other hand divides the risk in terms of the nature of impact i.e. impacts on the buildings manifest as physical risks and the other risks of market, regulations and organization reputation manifest as transition risks [2] [3].

\section{A. Introduction - Impact of Climate Change on Indian \\ Subcontinent}

As a background study to understand the variation in climate the Indian sub-continent and Asia is prone to, various literature sources have been studied and the impacts of these changes have been identified. The key risks brought out by IPCC reports include an increase in flooding for riverine, coastal and urban areas which may result in damage to infrastructure along with livelihood and settlements. Another study by [4] focuses on an increased risk of heat related mortality along with negative impact of heat and humidity on working hours for outdoor activities. [5] emphasizes on increased cooling and heating demands along with an increased risk of inundation while [6] have also warned against the rise in temperature and increased precipitation along with threat of ground water depletion. An impending water scarcity has also been brought out in a study undertaken by [7] for major cities (including Indian cities) throughout the world. [1]; [4]; [5]; [6]; [7]

\section{B. Vulnerability to Climatic and Non-Climatic Factors}

Globally, urban areas hold approximately half of the world's total population and is formed of most of the built assets and supports majority economic activities. Urban areas are not only at risk due to climate change but they carry out activities responsible for this change as well. The IPCC report also identifies that apart from climate based risks, rapid urbanization and growth in these cities has resulted in urban communities becoming highly vulnerable, especially within informal settlements on lands exposed to events of extreme weather. This issue of urbanity sprawling into the erstwhile inhabitable coastal and flood plains is just as much problematic in purview of vulnerability, as is the development of unplanned settlement that replace these land masses. The report describes the decrease in greens which not only contributes to the urban heat island effect but also decrease the land available for percolation of water which now gets added to the amount of storm water to be discharged by the already over-stressed stormwater drainage system [8]

This vulnerability of the built environment resulted due to both the climate and non-climate-based factors have been presented through a modified flow diagram of vulnerability presented in the IPCC 2014 report (fig. 1). The paper considers the climatic factors of high temperature, flooding and poor air quality and non-climatic factors of rapid urbanization and water scarcity. Risks pertaining to these factors are studied through the assessment framework. 


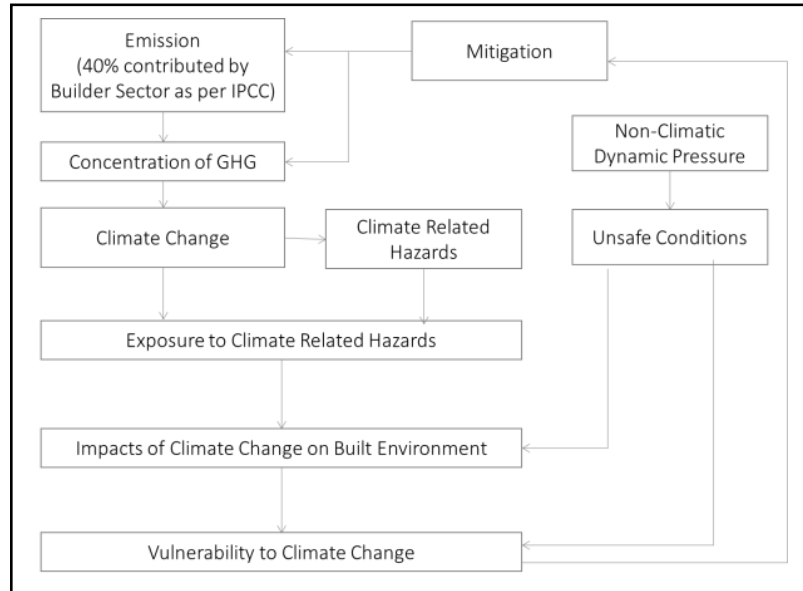

Fig 1: factors affecting built environment; adapted from [1]

It has been argued that the risk caused by a disaster is a product of the hazard occurring naturally and the number of people and their varying degree of vulnerability. Technically, hazard refers to "the natural events that may affect different places singly or in combination at different times". The three concepts of risk, hazards and vulnerability thus have been related through the following equation which has been employed to calculate risk within this study. [9]

$$
\mathrm{R}=\mathrm{H} \times \mathrm{V}
$$

\section{Research Gap}

Within the existing indicator-based frameworks studied, it is observed that there is an absence of methods which are suitable for the varied scales of micro and macro levels of building and cities respectively [10]. Also, a study by [11] states that development plans of cities have failed to explore the ways in which buildings and infrastructure can be adapted to the impacts of climate change. Further, the city level assessment indicators applicable to buildings and infrastructure studied lacks concerns beyond property inundation, urban heat island effect and occupant comfort. [12]; [11]; [13]; [14]; [15]; [1]

\section{Research Aim and Objectives}

The paper thus aims to prepare an assessment framework for climate change related risks to built-environment. The following research objectives would be undertaken to formulate the framework:

i) Identification of various unsafe conditions created by both climatic and non-climatic conditions affecting built environment and their direct impact

ii) Review of Indicators for assessment of vulnerability of the durability and operation of buildings to climate related risk

iii) Preparation of framework for climate change-based risk assessment

iv) Demonstration of framework on case study.

\section{LITERATURE REVIEW}

The literature studied has been divided to address the five climatic and non-climatic factors mentioned previously. Research papers on how these factors impact the built environment were searched on Google Scholar with key words impact of' (identified factors) 'on building operation' (building durability). A list of unsafe conditions and its direct tangible impact on the built environment has been identified and explained in the following paragraphs. About 29 indicators have been explored and derived from these conditions which have been further shortlisted to 14 on the basis of data available for inclusion within the risk assessment framework.

Within the climatic factor of flooding and non-climatic factor of rapid urbanization, unsafe conditions such as loss of green areas and subsequent reduction in percolation of storm water has been identified from a study by [16]. Other conditions identified include increase in surface run off, road length and length of storm water drainage affected along with risk to properties located in coastal or flood plains [16]. In another research, [17] had identified that increased instances of flooding may particularly damage properties located in areas with soil prone to cracking and subsidence. A study by [18] has further raised the concern of damage to pavement due to improper disposal of storm water or inundation while the effect of wind drive rains on building cladding has been stated by [19]. Another issue of exposure of larger properties to chlorides due to rise in sea level had been identified in a research by [20] and [21].

Unsafe conditions created due to rise in temperature included loss of vegetative heat sink that in turn raises risk of increase in temperature due to urban heat island effect and increased energy consumption due to cooling demand, as stated in papers by [16] and [22] respectively. Further, rise in temperature was also related to fall in efficiency of PV Cells as substantiated by [23]. Also study by [24] indicates premature deterioration of outdoor polymer based materials while [25] have observed an increase in incidents of electrical fires in older buildings.

Factor of poor air quality has been related to acid deposition and the subsequent damage to concrete structure as per research by [26] along with increasing the likelihood of additional changes in building HVAC system to maintain indoor air quality as suggested in study by [27]. The unsafe conditions created by water scarcity includes, as [7] suggest, increase in reclaiming waste water and carry out the additional changes to the water treatment infrastructure and also include water treatment at building level to reduce damage to plumbing system as observed by [28] in their research.

The risks corresponding to these unsafe conditions and the impact of climatic and non climatic factors on them are further taken up through survey conducted through Google forms. 23 architects, project managers and civil engineers with an experience of 3 years and above have been identified for survey and the results obtained have been analysed by both SPSS and manual means.

\section{ANALYSIS OF DATA}

The results of survey have been tested through Cronbach alpha reliability test which has been carried out on SPSS of the sample surveyed and 0.74 score was obtained that renders the survey acceptable. The survey results are further analysed for identification of relative importance index of these risks. The RII in each case would serve as impact if the hazard for final assessment of risk. The RII has been 
calculated through manual means using MS Excel and has been added to the final framework for assessment of risk.

$$
R I I=\frac{\sum w}{A * N}(0 \leq R I I \leq 1)
$$

In this case $\mathrm{w}=$ scale $\mathrm{x}$ corresponding number of respondents $\mathrm{A}=$ highest weightage (for calculation of this data, it is 5)

$\mathrm{N}=$ total number of respondents

TABLE I: RISK FRAMEWORK WITH DESCRIPTION AND RII

\begin{tabular}{|c|c|c|}
\hline $\mathbf{R N}$ & $\begin{array}{l}\text { Risk Description } \\
\text { (indicator) }\end{array}$ & RII \\
\hline 1 & Risk in location of property within coastal/flood plain & 0.809 \\
\hline 2 & $\begin{array}{l}\text { Risk of increased requirement for treatment of wastewater } \\
\text { (due to likelihood of water shortage) }\end{array}$ & 0.800 \\
\hline 3 & Risk of building located within site with expansive soil & 0.774 \\
\hline 4 & Risk of operational cost due to increase in cooling demand & 0.748 \\
\hline 5 & Risk in water logging of pavements located within site & 0.739 \\
\hline 6 & $\begin{array}{l}\text { Risk of increase in number of days with deteriorated air } \\
\text { quality }\end{array}$ & 0.739 \\
\hline 7 & $\begin{array}{l}\text { Risk of increased deterioration of concrete due to rise in sea } \\
\text { levels }\end{array}$ & 0.730 \\
\hline 8 & $\begin{array}{l}\text { Risk of increased corrosion of plumbing system due to poor } \\
\text { water quality }\end{array}$ & 0.713 \\
\hline 9 & Risk of decrease in vegetative heat sink in neighbourhood & 0.687 \\
\hline 10 & Risk of damage to building cladding due to excess moisture & 0.670 \\
\hline
\end{tabular}

\begin{tabular}{|l|l|c|}
$\mathbf{1 1}$ & Risk of increase in surface run off from adjacent properties & 0.652 \\
\hline $\mathbf{1 2}$ & $\begin{array}{l}\text { Risk of damage to polymer based outdoor materials due to } \\
\text { increase in thermal radiation exposure }\end{array}$ & 0.652 \\
\hline $\mathbf{1 3}$ & $\begin{array}{l}\text { Risk in decrease in efficiency of PV cells due to extreme } \\
\text { heat }\end{array}$ & 0.609 \\
\hline $\mathbf{1 4}$ & Risk of increase in electrical fires due to extreme heat & 0.600 \\
\hline
\end{tabular}

\section{A. Application of Risk Framework}

The above matrix has been utilized with data particular to Mumbai, Chennai and Delhi in order to compare their relative risk scores. Two of the risks of properties in expansive soil and number of electrical fires, with data missing have been removed. While the two risks of flooding of properties within coastal/flood plains and change in vegetative heat sink has been replaced with proxy indicators.

Since the values of different risks vary in their scale, the values for each risk have been normalized to score each city in a scale of 0 to 1 . For normalization, the technique used in Simple Additive Weighing has been considered given its scaling within 1 and 0

The normalized value for maximum criteria were obtained from $n \_i j=r \_i j /\left(r \_j \wedge \max \right)$

The normalized value for minimum criteria were obtained from $n \_i j=\left(r \_j^{\wedge} \min \right) /\left(r_{-} i j^{\wedge}\right)$

For a matrix with $\mathrm{i}=$ column number, $\mathrm{j}=$ row number.

TABLE II: FUtURE RISK ASSESSMENT FOR DELHI, MUMBAI AND CHENNAI

\begin{tabular}{|c|c|c|c|c|c|c|}
\hline$\#$ & Risk Description & RII & Delhi & Chennai & Mumbai & Source \\
\hline 1 & properties located within coastal/ flood plains & 0.809 & 2 & 5 & 5 & $\begin{array}{l}\text { Proxy Indicator Flood Vulnerability Index } \\
\text { [29] }\end{array}$ \\
\hline 2 & $\begin{array}{l}\text { increased requirement for water treatment } \\
\text { (future water risk-2040) }\end{array}$ & 0.800 & 5 & 5 & 5 & $\begin{array}{lll}\text { Data from Municipal reports } & \text { on } \\
\text { Groundwater table [29] [34] } & & \\
\end{array}$ \\
\hline 3 & $\begin{array}{l}\text { increased requirement for cooling } \\
\text { (temperature level }-2050 \text { ) }\end{array}$ & 0.748 & 5 & 3 & 3 & {$[30][35]$} \\
\hline 4 & $\begin{array}{l}\text { increased risk to concrete due to rise in sea } \\
\text { levels } \\
\text { (sea level rise }-2050 \text { percentage pixels of area } \\
\text { submerged under water) }\end{array}$ & 0.730 & 0 & 12.46 & 48.78 & $\begin{array}{l}\text { Since proximity of coastline is considered, } \\
\text { Chennai and Mumbai scores } 1 \text { and Delhi is } \\
\text { allotted } 0 \text { score [36] }\end{array}$ \\
\hline 5 & $\begin{array}{l}\text { waterlogging of pavements due to increased } \\
\text { precipitation }\end{array}$ & 0.739 & 189.7 & 396.84 & 375 & $\begin{array}{l}\text { National Flood Vulnerability Assessment } \\
\text { System - Bhuvan Application [29] }\end{array}$ \\
\hline 6 & $\begin{array}{l}\text { damage to plumbing system due to poor water } \\
\text { quality }\end{array}$ & 0.713 & 19 & 9 & 0 & [31] [32] \\
\hline 7 & $\begin{array}{l}\text { increased risk of UHI due to decreased } \\
\text { vegetative heat sink }\end{array}$ & 0.687 & 56.2 & 43.2 & 12.3 & Proxy Indicator NDVI [28] \\
\hline 8 & $\begin{array}{lllll}\text { modification of HVAC system } & \text { due } & \text { to } \\
\text { deteriorated air quality (PM } 2.5 & \text { conc. } & \text { In } \\
\text { ug/cubm as per } 2050 \text { projection }) & & & \\
\end{array}$ & 0.739 & 110 & 110 & 110 & $\begin{array}{l}\text { CAAQM dashboard } \\
\text { Www.aap.cpcbecr.com } \\
\text { [37] }\end{array}$ \\
\hline 9 & $\begin{array}{l}\text { damage to building cladding due to wind driven } \\
\text { rain }\end{array}$ & 0.670 & 3 & 3 & 30 & [19] \\
\hline 10 & $\begin{array}{l}\text { decrease in durability of polymer based outdoor } \\
\text { material due to UV exposure (future UV level) }\end{array}$ & 0.652 & 13 & 13 & 14 & [30] [38] \\
\hline 11 & $\begin{array}{lllll}\begin{array}{l}\text { increased surface run off from adjacent } \\
\text { properties }\end{array} & & & & \\
\end{array}$ & 0.652 & 111.69 & 364 & 365.94 & $\begin{array}{l}\text { National Flood Vulnerability Assessment } \\
\text { System - Bhuvan Application [28] }\end{array}$ \\
\hline 12 & $\begin{array}{l}\text { increased risk to } \mathrm{PV} \text { cells due to rise in } \\
\text { temperature (monthly avg above } 40 \text { deg } C \\
\text { adjusted with respect to rise in temp. 2050) }\end{array}$ & 0.609 & 4 & 1 & 0 & [33] [35] \\
\hline
\end{tabular}

The values within each cell are then normalized and the resulting table is given below: 
TABLE III: NORMALIZATION OF FUTURE CLIMATE RISK VALUES

\begin{tabular}{|l|l|l|l|}
\hline RN & Risk Description \\
\hline $\mathbf{1}$ & properties located within coastal/ flood plains \\
\hline $\mathbf{2}$ & increased requirement for water treatment \\
\hline $\mathbf{3}$ & increased requirement for cooling \\
\hline $\mathbf{4}$ & increased risk to concrete due to rise in sea levels \\
\hline $\mathbf{5}$ & waterlogging of pavements due to increased precipitation (mm/100yrs) \\
\hline $\mathbf{6}$ & damage to plumbing system due to poor water quality \\
\hline $\mathbf{7}$ & increased risk of UHI due to decreased vegetative heat sink - proxy ND \\
\hline $\mathbf{8}$ & modification of HVAC system due to deteriorated air quality \\
\hline $\mathbf{9}$ & damage to building cladding due to wind driven rain (current WDRI) \\
\hline $\mathbf{1 0}$ & decrease in durability of polymer based outdoor material due to UV exp \\
\hline $\mathbf{1 1}$ & increased surface run off from adjacent properties (current mm) \\
\hline $\mathbf{1 2}$ & increased risk to PV cells due to rise in temperature \\
\hline \multicolumn{5}{|c|}{} \\
\hline \multicolumn{5}{|c|}{ TABLE IV: FUTURE RISK SCORE OF EACH CITY } \\
\hline \multicolumn{5}{|c|}{ Chennai } & Mumbai \\
\hline Risk Score & $\mathbf{5 . 3 1}$ & $\mathbf{5 . 7 3}$ & $\mathbf{6 . 8 9}$ \\
\hline
\end{tabular}

A multiplication of RII from each of the scores is then summed up to give relative risk scores for each city. As observed from Table IV, Delhi scores the lowest in terms of climate change-based risks followed closely by Chennai, and Mumbai is exposed to more risk.

The assessment undertaken in Table II and III and the subsequent score in Table IV is with respect to future climatic conditions have been considered. Future risks pertaining to water stress for the year 2040 [34], rise in temperature by 2050 [35], increased risk of sea level rise by 2050 [36], deterioration of air quality by 2050 [37] and UV levels (which has been projected to remain same for 2050) [38]. Conditions pertaining to remaining risks have been considered based on current values obtained from the sources as per Table II.

A validation of results has been carried out through application of the risk assessment framework on the three cities based on current climatic conditions and the results have been substantiated by the extreme climate related events experienced within these cities. Based on the current climatic conditions and through normalization of values, the final normalized values and risk scores have been given in Table $\mathrm{V}$.

TABLE V:WEIGHTED AND NORMALIZED CURRENT CLIMATE

\begin{tabular}{|l|l|l|l|l|l|}
\hline $\mathbf{R N}$ & Risk Description & RII & Delhi & Chennai & Mumbai \\
\hline $\mathbf{1}$ & $\begin{array}{l}\text { properties located within } \\
\text { coastal/ flood plains }\end{array}$ & 0.809 & 0.32 & 0.81 & 0.81 \\
\hline $\mathbf{2}$ & $\begin{array}{l}\text { increased requirement for } \\
\text { water treatment }\end{array}$ & 0.800 & 0.26 & 0.78 & 0.52 \\
\hline $\mathbf{3}$ & $\begin{array}{l}\text { increased requirement for } \\
\text { cooling }\end{array}$ & 0.748 & 0.77 & 0.96 & 0.78 \\
\hline $\mathbf{4}$ & $\begin{array}{l}\text { increased risk to concrete } \\
\text { due to rise in sea levels }\end{array}$ & 0.730 & 0.00 & 0.76 & 0.76 \\
\hline $\mathbf{5}$ & $\begin{array}{l}\text { waterlogging of pavements } \\
\text { due to increased } \\
\text { precipitation (mm/100yrs) }\end{array}$ & 0.739 & 0.36 & 0.75 & 0.71 \\
\hline $\mathbf{6}$ & $\begin{array}{l}\text { damage to plumbing } \\
\text { system due to poor water } \\
\text { quality }\end{array}$ & 0.713 & 0.73 & 0.35 & 0.00 \\
\hline $\mathbf{7}$ & $\begin{array}{l}\text { increased risk of UHI due } \\
\text { to decreased vegetative } \\
\text { heat sink - proxy NDVI }\end{array}$ & 0.687 & 0.16 & 0.21 & 0.72 \\
\hline
\end{tabular}

\begin{tabular}{|c|c|c|c|c|c|c|}
\hline & RII & Delhi & \multicolumn{2}{|c|}{ Chennai } & \multicolumn{2}{|c|}{ Mumbai } \\
\hline & 0.809 & 0.40 & \multicolumn{2}{|c|}{1.00} & \multicolumn{2}{|c|}{1.00} \\
\hline & 0.800 & 1.00 & \multicolumn{2}{|c|}{1.00} & \multicolumn{2}{|c|}{1.00} \\
\hline & 0.748 & 1.00 & \multicolumn{2}{|c|}{0.60} & \multicolumn{2}{|c|}{0.60} \\
\hline & 0.730 & 0.00 & \multicolumn{2}{|c|}{0.26} & \multicolumn{2}{|c|}{1.00} \\
\hline & 0.739 & 0.48 & \multicolumn{2}{|c|}{1.00} & \multicolumn{2}{|c|}{0.94} \\
\hline & 0.713 & 1.00 & \multicolumn{2}{|c|}{0.47} & \multicolumn{2}{|c|}{0.00} \\
\hline $\mathrm{VI}$ & 0.687 & 0.22 & \multicolumn{2}{|c|}{0.28} & \multicolumn{2}{|c|}{1.00} \\
\hline & 0.739 & 1.00 & \multicolumn{2}{|c|}{1.00} & \multicolumn{2}{|c|}{1.00} \\
\hline & 0.670 & 0.10 & \multicolumn{2}{|c|}{0.10} & \multicolumn{2}{|c|}{1.00} \\
\hline oosure & 0.652 & 0.93 & \multicolumn{2}{|c|}{0.93} & \multicolumn{2}{|c|}{1.00} \\
\hline & 0.652 & 0.31 & \multicolumn{2}{|c|}{0.99} & \multicolumn{2}{|c|}{1.00} \\
\hline & 0.609 & 1.00 & \multicolumn{2}{|c|}{0.25} & \multicolumn{2}{|c|}{0.00} \\
\hline 8 & \multicolumn{2}{|c|}{$\begin{array}{l}\text { modification of HVAC } \\
\text { system due to deteriorated } \\
\text { air quality }\end{array}$} & 0.739 & 0.70 & 0.49 & 0.28 \\
\hline 9 & \multicolumn{2}{|c|}{$\begin{array}{l}\text { damage to } \quad \text { building } \\
\text { cladding due to wind } \\
\text { driven rain (current WDRI) }\end{array}$} & 0.670 & 0.07 & 0.07 & 0.67 \\
\hline 10 & \multicolumn{2}{|c|}{$\begin{array}{l}\text { decrease in durability of } \\
\text { polymer based outdoor } \\
\text { material due to UV } \\
\text { exposure }\end{array}$} & 0.652 & 0.59 & 0.59 & 0.64 \\
\hline 11 & \multicolumn{2}{|c|}{$\begin{array}{l}\text { increased surface run off } \\
\text { from adjacent properties } \\
\text { (current } \mathrm{mm})\end{array}$} & 0.652 & 0.19 & 0.63 & 0.64 \\
\hline 12 & \multicolumn{2}{|c|}{$\begin{array}{l}\text { increased risk to PV cells } \\
\text { due to rise in temperature }\end{array}$} & 0.609 & 0.63 & 0.00 & 0.00 \\
\hline & & SCORE & & 4.79 & 6.38 & 6.52 \\
\hline
\end{tabular}

\section{B. Results}

As observed through the risk scores above, Mumbai and Chennai have similar current risk scores. Although Chennai has a higher or similar risk score for the first five indicators which have greater weightage in terms of RII, but because of the higher risk Mumbai faces due to lower green cover and higher intensity of Wind Driven Rain along with greater UV exposure, built environment faces greater risk in the city. Delhi scores considerably lower than the two. This can also be observed from the events of flood in Mumbai in 2017 and 2019 along with Chennai floods in 2015, 2017 and water crisis in 2019. However, the future climate risks as projected in Table IV shows similar climate risks faced by Delhi and Chennai but projects higher risk for Mumbai.

\section{CONCLUSION}

Based on the application of framework following it can be concluded that the application heavily relies on availability of data for all the buildings/cities/regions selected. This is important because the risk assessment is not probability based. It scores the subjects relative to one another. Because of this, the framework can also be applied at various levels with indicators adjusted to suit the scale of the subjects.

The risk assessment across the three cities can be considered appropriate with respect to the recent events of flooding and water scarcity. But it is also important to note that these indicators identify vulnerability of the built environment and not of human lives. The water stress and flood related indicators have been given higher RII and consequently Mumbai and Chennai have scored higher.

\section{A. Future Scope}

The study has been conducted based on existing and proposed indicators that have been derived from the studies on impact of climate change on buildings. However, considering the area of research itself, especially for the Indian sub- 
continent is at a nascent stage, and owing to the urgency faced by the building sector regarding resilience to climate related risks, it is important that more studies are conducting establishing relation between climate change and building operation and maintenance. Such studies with help to diversify the indicators used and also help formulate more reliable indicators that can give an accurate description of the risks likely to occur.

\section{ACKNOWLEDGMENT}

I wish to thank Prof. Dr. Chaitali Basu for her guidance throughout the study. I also extend my gratitude to Prof. Dr. V.K. Paul for his valuable advice. I am also grateful to my Thesis guide Architect Varun Seth for his critical reviews.

\section{REFERENCES}

[1] Ürge-Vorsatz, D., Lucon, O., Zain Ahmed, A., Akbari, H., Bertoldi, P., Cabeza, L.F., Eyre, N., et al. (2014), "Buildings. In: Mitigation. Working Group III contribution to the Fifth Assessment Report of the Intergovernmental Panel of Climate Change.”, pp. 671-738.

[2] EUROPEAN COMMISSION, 2011. Guidelines for Project Managers: Making Vulnerable Investment Climate Resilient, London: EUROPEAN COMMISSION.

[3] Urban Land Institute, 2015. A GUIDE FOR ASSESSING CLIMATE CHANGE RISK, Washington DC: ULI

[4] Woetzel, J., Pinner, D., Samandari, H., Engel, H., Krishnan, M., Boland, B. and Powis, C. (2020), "Climate Risk and response", No. January, pp. 1-144.

[5] OECD. (2018), "Climate-resilient Infrastructure. Policy Perspectives. OECD Environment Policy Paper No. 14", No. 14.

[6] Naswa, P. and Garg, A. (2011), "Managing climate-induced risks on Indian infrastructure assets", Current Science, Vol. 101 No. 3, pp. 395404.

[7] Hofste, R. W., Reig, P. \& Schleifer, L., 2019. wri.org. [Online] Available at: https://www.wri.org/blog/2019/08/17-countries-homeone-quarter-world-population-face-extremely-high-water-stress. [Accessed 27 March 2020].

[8] Sutton, M.A., Billen, G., Bleeker, A., Erisman, J.W., Grennfelt, P., van Grinsven, H., Grizzetti, B., et al. (2011), "Technical summary", The European Nitrogen Assessment, pp. xxxv-lii.

[9] Wisner, B., Blaikie, P., Cannon, T. and Davis, I. (2014), "At risk: natural hazards, peoples vulnerability and disasters", At Risk: Natural Hazards Peoples Vulnerability and Disasters, pp. 1-471.

[10] Cerè, G., Rezgui, Y. and Zhao, W. (2017), "Critical review of existing built environment resilience frameworks: Directions for future research", International Journal of Disaster Risk Reduction, Vol. 25 No. May, pp. $173-189$

[11] Sharma, D. and Tomar, S. (2010), "Mainstreaming climate change adaptation in Indian cities", Environment and Urbanization, Vol. 22 No. 2, pp. 451-465.

[12] Feldmeyer, D., Wilden, D., Kind, C., Kaiser, T., Goldschmidt, R., Diller, C. and Birkmann, J. (2019), "Indicators for monitoring urban climate change resilience and adaptation", Sustainability (Switzerland), Vol. 11 No. 10, available at:https://doi.org/10.3390/su11102931.

[13] Smiciklas, J., Prokop, G., Stano, P. and Sang, Z. (2017), Collection Methodology for Key Performance Indicators for Smart Sustainable Cities, available https://www.unece.org/fileadmin/DAM/hlm/documents/Publications/U 4SSC-CollectionMethodologyforKPIfoSSC-2017.pdf.

[14] Sida. (2011), "Environmental and Climate Change Indicators", No. October, p. 58

[15] TERI. (2013), "Climate Proofing Guwahati, Assam-City Resilience Strategy and Mainstreaming Plan", No. June, pp. 1-70.

[16] Gupta, S., 2017. Impact of Floods in Delhi, New Delhi: CLIMATRANS
[17] Prof David G.Toll - Durham University. (2004), "the Impact of Changes in the Water Table and Soil Moisture on Structural Stability of Buildings and Foundation Systems”, Durham Research Online, Vol. 44 No. April, pp. 0-103.

[18] Adlinge, S.S. and Gupta, P.A.K. (n.d.). "Pavement Deterioration and its Causes", pp. 9-15.

[19] Chand, I. and Bhargava. (2004), "Estimation of driving rain index for nigeria", Architectural Science Review, Vol. 47 No. 2, pp. 103-106.

[20] Gao, X.J. and Wang, X.Y. (2017), "Impacts of globalwarming and sea level rise on service life of chloride-exposed concrete structures", Sustainability (Switzerland), Vol. 9 No. 3, available at:https://doi.org/10.3390/su9030460.

[21] Stewart, M.G., Wang, X. and Nguyen, M.N. (2011), "Climate change impact and risks of concrete infrastructure deterioration", Engineering Structures, Vol. 33 No. 4, pp. 1326-1337.

[22] Yau, Y.H. and Hasbi, S. (2013), "A review of climate change impacts on commercial buildings and their technical services in the tropics", Renewable and Sustainable Energy Reviews, Elsevier, Vol. 18, pp. 430-441.

[23] Dubey, S., Sarvaiya, J.N. and Seshadri, B. (2013), "Temperature dependent photovoltaic (PV) efficiency and its effect on PV production in the world - A review", Energy Procedia, Elsevier B.V., Vol. 33, pp. 311-321.

[24] Andrady, A.L., Hamid, H.S. and Torikai, A. (2003), "Effects of climate change and UV-B on materials", Photochemical and Photobiological Sciences, Vol. 2 No. 1, pp. 68-72.

[25] Jeong, M.C. and Kim, J. (2019), "Prediction and analysis of electrical accidents and risk due to climate change", International Journal of Environmental Research and Public Health, Vol. 16 No. 16, available at:https://doi.org/10.3390/ijerph16162984.

[26] Xie, S., Qi, L. and Zhou, D. (2004), "Investigation of the effects of acid rain on the deterioration of cement concrete using accelerated tests established in laboratory", Vol. 38 No. x, pp. 4457-4466.

[27] Wilby, R.L. (2018), "A review of climate change impacts on the built environment", Planning for Climate Change: A Reader in Green Infrastructure and Sustainable Design for Resilient Cities, Vol. 33 No 1, pp. 34-41.

[28] Lee, H., Rasheed, U. and Kong, M. (2018), "A study on the comparison of corrosion in water supply pipes due to tap water (TW) and reclaimed water (RW)", Water (Switzerland), Vol. 10 No. 4, available at:https://doi.org/10.3390/w10040496.

[29] ISRO, 2020. Bhuvan Application. [Online] Available at: https://bhuvan.nrsc.gov.in/bhuvan_links.php\# [Accessed 22 April 2020]

[30] world weather, 2020. worldweatheronline.com. [Online] Available at: worldweatheronline.com [Accessed 15 April 2020].

[31] Bureau of Indian Standards, 2019. Press Release. [Online] Available at: http://164.100.117.97/WriteReadData/userfiles/Categorization.pdf,[Acc essed 20 April 2020].

[32] Archana, A., Kaur, P. and Kanodia, S. (n.d.). "Evaluating Microbial \& Chemical Quality of Delhi-NCR Drinking Water, Enhancing its Standard \& Spreading Mass Awareness", pp. 14-35.

[33] . Time and Date AS, 2020. timeanddate.com. [Online] Available at: http://www.timeanddate.com [Accessed 15 April 2020].

[34] World Resources Institute, 2020. https://www.wri.org/. [Online] Available at: https://www.wri.org/applications/aqueduct/water-riskatlas/ [Accessed 22 May 2020].

[35] Kumar, K. et al., 2006. High-resolution climate change scenarios for India for the 21st Century. Current Science, 90(3), pp. 334-345.

[36] Climate Central, 2020. www.coastal.climatecentral.org. [Online] Available at: https://coastal.climatecentral.org/map/ [Accessed 22 May 2020].

[37] Kumar, R. et al., 2018. How Will Air Quality Change in South Asia by 2050?. Journal of Geophysical Research: Atmospheres, Volume 123, p. 1840-1864.

[38] Bais, A. et al., 2011. Projections of UV radiation changes in the 21st century: impact of ozone recovery and cloud effects. Atmospheric Chemistry and Physics, p. 7533-7545. 